\title{
Foraging use of cultivated fields by the Houbara Bustard Chlamydotis undulata fuertaventurae Rothschild and Hartert, 1894 on Fuerteventura (Canary Islands)
}

\author{
FÉLIX M. MEDINA
}

\section{Summary}

The Houbara Bustard on Fuerteventura uses cultivated fields (gavias) as feeding sites, finding in these a high-level resource of easy access. A total of 521 visits were observed during this study, 81 to abandoned gavias, 139 to cultivated, and 301 to ploughed ones. This use was correlated with the total vegetation cover, as well as with cover by herbaceous plants and by alfalfa Medicago sativa. The relationship with invertebrate abundance was negative. Cultivated gavias were selected in relation to their alfalfa cover, abandoned gavias in relation to their herbaceous cover, and ploughed gavias were selected in relation to total vegetation cover, cover of herbaceous plants, Launaea arborescens and Salsola vermiculata cover, and vegetation height. Figs, present in ploughed gavias only, were a highly favoured food resource. Of the three study localities, Lajares was most visited by Houbaras ( 357 visits), followed by Triquivijate (105) and Tefía (59). This use was not correlated with the population of Houbaras in each locality but with the resources that were found in them. The gavias were used in all seasons of the year, mainly in summer, and less so in spring. In summer, use was correlated with herbaceous plant cover and associated to the presence of figs, and in winter with herbaceous cover; in autumn there was no overall selection for variables; in spring, selection was negative with respect to invertebrate availability. This predictable food resource is a real advantage for the maintenance of Houbara populations and contributes to the conservation of the species on Fuerteventura.

\section{Introduction}

The Canarian Houbara Bustard Chlamydotis undulata fuertaventurae is restricted to Fuerteventura, Lanzarote and Graciosa. The population of this endemic subspecies has been estimated at 527 birds: 18 on Graciosa, 268 on Lanzarote and 241 on Fuerteventura (Martín et al. 1997). The Houbara lives in semi-arid habitat with a vegetation characterized by xerophytic and coastal scrubland made up of several species of the families Euphorbiaceae and Chenopodiaceae. These habitats, however, have been altered drastically by intensive agriculture and overgrazing over the past centuries.

Agricultural zones produce environments where the availability and predictability of food resources is very high for the Houbaras (Domínguez-Casanova 1989). This high availability, together with the nature of the vegetation cover and 
its floristic composition, is very important in determining the distribution and abundance of birds (Thompson and Fritzell 1989), and acts as a proximate factor in guiding habitat selection (Hildén 1965, Rotenberry and Wiens 1980, Osborne 1984, Rice et al. 1984, Wiens 1985). Also, the constant presence of this resource over time and the bird's capacity to learn how best to exploit it (Pyke et al. 1977) represent a substantial advantage, since the net rate of energy is maximized and the time spent in searching and handling food items is minimized, according to foraging theory (Schoener 1971, Pyke et al. 1977, Pyke 1984, Krebs and Davies 1993, Brown et al. 1994). Thus these cultivated areas have produced a new food resource that has been utilized by several groups of birds, notably of the family Otididae, e.g. Great Bustard Otis tarda and Little Bustard Tetrax tetrax (Hidalgo de Trucios and Carranza 1990, Johnsgard 1991, Martínez 1991a, Alonso et al. 1995, Martínez and de Juana 1995) and many others, some of which have become agricultural specialists (see e.g. Tucker and Heath 1994).

The Houbara's diet in the Canary Islands comprises both animal and plant material. Insects are consumed in greatest quantity and ants Messor maurus and beetles Zophosis plicata are the most important of these (Collins 1993). Vegetable food comprises mainly annual plants, flowers of Launaea arborescens and fruits of Lycium intricatum (Collins 1993). In agricultural areas, Houbaras eat cultivated peas, chickpeas and trefoils (Leguminosae) (Bannerman 1963, Cramp and Simmons 1980, Collins 1984, 1993). The presence of these agricultural areas within the Houbara's range and their use for feeding encouraged the Canary Island government to include them in the species's recovery plan (F. DomínguezCasanova and G. Díaz 1985, unpubl. report), where it was considered that food availability in the Houbara's habitat had diminished considerably, so that it was important to increase the habitat's carrying capacity.

Cultivated fields present varied conditions in relation to the lack of rainfall and state of cultivation and therefore have different vegetal composition and food availability that may affect their use by Houbaras. The aim of the present study was to investigate the use of cultivated fields by the Houbara Bustard in Fuerteventura. The principal objectives were: (1) to study the foraging use of cultivated fields by Houbaras, recording the frequency of birds' visits and their patterns of spatial and temporal variation and (2) to determine what factors affect preferences for particular types of cultivation and the spatial and temporal variation involved. This information will allow evaluation of the potential importance of cultivated fields for Houbara populations in those periods when food availability is reduced and their contribution to the maintenance and conservation of the Houbara population on Fuerteventura.

\section{Study area}

The study was carried out in Fuerteventura, a low-lying island of $1,662 \mathrm{~km}^{2}$, rising to $807 \mathrm{~m}$ above sea-level (at Pico de La Zarza). Its landscape is affected by erosive-sedimentary processes (Galván and Criado 1985) and comprises extensive stony or bare plains, and gentle slopes. The climate is mainly warm subdesertic to desertic, although it is influenced by sea spray and the proximity to the African continent (10o km away at the closest point). Annual rainfall is less than 
$200 \mathrm{~mm}$, and the mean annual temperature is $19.1^{\circ} \mathrm{C}$, though winds from the Sahara can lead to values of up to $40{ }^{\circ} \mathrm{C}$ (Marzol-Jaén 1984). Rainfall is concentrated from November until January, and in summer (June-August) there is virtually none; at other times there is less than $20 \mathrm{~mm}$. Mean tempertatures range from $23.3{ }^{\circ} \mathrm{C}$ (August) to $15.6^{\circ} \mathrm{C}$ (January) (Galván and Criado 1985).

The vegetation is xerophytic shrubland from which trees are largely absent (Galván and Criado 1985). The plant community of coastal and sandy habitats is characterized by Euphorbia paralias, Traganum moquinii, and species of Suaeda. Elsewhere the semi-natural vegetation on the island, with a low shrub cover, is located in the central plains, where the main species present are Launaea arborescens, Salsola vermiculata and Lycium intricatum.

The typical mode of cultivation in Fuerteventura produces fields called "gavias". Gavias are formed on deep and productive soils, which are ploughed before the seasonal rainfall period, allowing profitable agriculture despite the low rainfall (Galván and Criado 1985). Farming is based on lentils, chickpeas, peas and especially alfalfa, because of its resistance to water salinity. Production is related to rainfall, and when rain is not sufficient, many gavias are abandoned, when species such as Launaea arborescens, Salsola vermiculata and Atriplex semibaccata colonize. The reduction in agriculture in the archipelago and the lack of water result in a fragmentation of cultivated areas. It is possible to distinguish three types of gavias, differing in the development of their vegetation: cultivated, ploughed and abandoned.

\section{Methods}

The study was carried out between September 1994 and August 1995. This period was divided in four seasons following Fuerteventura's annual cycle of temperature and precipitation (Marzol-Jaén 1984, Galván and Criado 1985): autumn (September-November), winter (December-February), spring (March-May), and summer (June-August).

Three localities were selected, in different parts of the island where both Houbaras and gavias were found: Lajares in north of the island, Tefía in the central part and Triquivijate in the south-central area. There were no cultivated gavias in Tefía but the other localities included all three types of gavias, 26 in total (12 ploughed, three cultivated and 11 abandoned). In each gavia type the vegetation characteristics and the invertebrate availability were measured monthly.

\section{Vegetation characteristics}

Houbaras tend to select areas with taller shrubs (Martín et al. 1996) and consume several plant species, including flowers of Launaea arborescens (Collins 1993), so the following variables were considered: vegetation cover, vegetation height and the number of flowers of Launaea arborescens. Vegetation cover was studied by the line-intercept method (50 m length; Kent and Coker 1992). A line was established along one diagonal of each gavia, and was retained throughout the study period. The height of 30 plants was measured in each gavia along this line and the flowers (present all year) of 30 Launaea plants were counted. 


\section{Invertebrate availability}

Most prey consumed by Houbaras are ants, beetles and grasshoppers (Collins 1993). Samples of invertebrates were counted by direct observation on the ground and within the vegetation. In each gavia, five ground samples were taken using a quadrat of $1 \mathrm{~m}^{2}$. Within the vegetation, 30 samples were taken, each from one plant and each covering $4,000 \mathrm{~cm}^{3}$ (using a quadrat of 400 $\mathrm{cm}^{2}$, invertebrates being counted $10 \mathrm{~cm}$ into vegetation). All potential prey items within the sampling areas were counted as a measure of invertebrate availability (Hutto 1990, Wolda 1990). The biases inherent in sampling by direct observation were overcome by taking a large number of samples (Cooper and Whitmore 1990).

\section{Frequency of visits}

To study the visiting frequency and use of gavias by Houbaras, four visits were made to each locality every month, in the afternoon (16h oo-20h oo), the Houbaras' main feeding periods (Hinz and Heiss 1989), although Mian (1986) observed possible feeding in cultivated gavias in the evening $(21 \mathrm{~h} \mathrm{oo})$. To confirm that the study times coincided with the main period of use by Houbaras, a daily log of use was kept at each locality, dividing the day into three periods: 7 h $00-11 \mathrm{~h} \mathrm{o0}$, 11h oo $-16 \mathrm{~h}$ oo (excluding $12 \mathrm{~h}$ oo $-13 \mathrm{~h}$ oo to give comparable periods of four hours) and $16 \mathrm{~h}$ oo - 20h oo. Houbaras used the gavias mainly in the afternoon with 97 visits, while in the morning there were only 17 visits altogether (KruskalWallis test, $\left.\chi^{2}=21.79 ; d f=2 ; P<0.001 ; n=30\right)$. In total, 144 days of observations were made during 10 months (September-June); only visits by Houbaras for feeding were included.

\section{Results}

\section{Vegetation characteristics}

The spatial characteristics recorded in each gavia are shown in Table 1 . The cultivated gavias had higher values of vegetation cover than the other two types (log-transfomed, $F_{2,309}=282.41 ; P<0.001$ ). Moreover, each gavia type had a distinct pattern of species coverage. The vegetation height also showed significant variation between gavia types $\left(F_{2,309}=32.07 ; P<0.001\right)$. The flowers of Launaea arborescens were present in ploughed and abandoned gavias only, being more numerous in plough.

Seasonal variation in the coverage by different plant species is shown in Figure 1. The most significant variations were in the total vegetation cover of cultivated gavias with a large increase in autumn, followed by a decrease through to summer $\left(\chi^{2}=23.21 ; d f: 2 ; P<0.001\right)$; these changes coincided with alfalfa cover. Herbaceous cover was greatest in winter and spring. In the other types of gavia, seasonal variation in the variables was not significant $(P>0.05)$. The number of flowers of Launaea did not vary with the season, but maximum values were observed in spring (log-transformed, Scheffé test, $F_{3,308}=0.87 ; P=0.45$ ). 
Table 1. Spatial variation in the vegetation characteristics measured in each gavia type.

\begin{tabular}{|c|c|c|c|c|c|}
\hline \multirow[t]{2}{*}{ Gavia type } & \multirow[t]{2}{*}{ Variable } & \multicolumn{3}{|c|}{ Locality } & \multirow[b]{2}{*}{ Total } \\
\hline & & Lajares & Tefía & Triquivijate & \\
\hline \multirow[t]{9}{*}{ Ploughed } & Covtot & $16.27 \pm 15.80$ & $0.31 \pm 0.08$ & $6.21 \pm 3.91$ & $7 \cdot 56 \pm 11.75$ \\
\hline & CovMesa & - & - & - & - \\
\hline & CovHerb & $8.57 \pm 17.49$ & - & $0.83 \pm 1.54$ & $3.14 \pm 10.81$ \\
\hline & CovLaar & $7.19 \pm 6.00$ & $0.26 \pm 0.66$ & $2.45 \pm 1.16$ & $3.30 \pm 7.74$ \\
\hline & CovSave & $0.26 \pm 0.45$ & $0.05 \pm 0.35$ & $0.02 \pm 0.06$ & $0.11 \pm 0.39$ \\
\hline & CovChto & $0.03 \pm 0.12$ & - & - & $0.01 \pm 0.07$ \\
\hline & CovAtse & $0.19 \pm 0.57$ & - & $2.92 \pm 3.28$ & $1.04+1.25$ \\
\hline & FlowLaar & $14.53 \pm 29.02$ & $0.45 \pm 1.12$ & $5.7^{2 \pm 4} .07$ & $6.90 \pm 17.92$ \\
\hline & Height $(\mathrm{cm})$ & $31.88 \pm 14.38$ & $11.09 \pm 10.68$ & $17.31 \pm 1.99$ & $20.09 \pm 15.07$ \\
\hline \multirow[t]{9}{*}{ Cultivated } & Covtot & $66.37 \pm 20.08$ & - & $70.68 \pm 20.74$ & $68.52 \pm 20.11$ \\
\hline & CovMesa & $44.11 \pm 21.34$ & - & $42.80 \pm 40.60$ & $43.39 \pm 28.60$ \\
\hline & CovHerb & $21.49 \pm 22.76$ & - & $3.67 \pm 5.51$ & $12.58 \pm 20.64$ \\
\hline & CovLaar & - & - & - & - \\
\hline & CovSave & $0.69 \pm 2.61$ & - & - & $0.35 \pm 2.14$ \\
\hline & CovChto & $0.03 \pm 0.08$ & - & - & $0.15 \pm 0.07$ \\
\hline & CovAtse & $0.19 \pm 0.61$ & - & $24.22 \pm 22.84$ & $12.20 \pm 17.21$ \\
\hline & FlowLaar & - & - & - & - \\
\hline & Height $(\mathrm{cm})$ & $30.85 \pm 9.70$ & - & $11.66 \pm 4.58$ & $21.25 \pm 12.35$ \\
\hline \multirow[t]{9}{*}{ Abandoned } & Covtot & $15.30 \pm 8.46$ & $11.80 \pm 5.62$ & $22.75 \pm 1.92$ & $16.62 \pm 6.80$ \\
\hline & CovMesa & - & - & - & - \\
\hline & CovHerb & $5.09 \pm 9.96$ & $0.06 \pm 0.17$ & $0.13 \pm 0.46$ & $1.76 \pm 4.64$ \\
\hline & CovLaar & $3.14 \pm 1.69$ & $7.41 \pm 4.45$ & $0.32 \pm 0.60$ & $3.62 \pm 4.56$ \\
\hline & CovSave & $6.91 \pm_{4.27}$ & $3.98 \pm 3.45$ & $22.30 \pm 1.80$ & $11.06 \pm 6.29$ \\
\hline & CovChto & $0.16 \pm 0.29$ & $0.20 \pm 0.36$ & - & $0.12 \pm 0.34$ \\
\hline & CovAtse & - & $0.11 \pm 0.21$ & - & $0.04 \pm 0.19$ \\
\hline & FlowLaar & $0.51 \pm 1.14$ & $1.73 \pm 1.94$ & $2.64 \pm 1.98$ & $1.59 \pm 1.90$ \\
\hline & Height $(\mathrm{cm})$ & $22.55 \pm 3.37$ & $30.21 \pm 6.93$ & $52.68 \pm 5.57$ & $35.15 \pm 9.80$ \\
\hline
\end{tabular}

Covtot, total cover; CovMesa, cover of Medicago sativa; CovHerb, cover of herbaceous plants; CovLaar, cover of Launaea arborescens; CovSave, cover of Salsola vermiculata; CovChto, cover of Chenoleoides tomentosa; CovAtse, cover of Atriplex semibaccata. Cover is expressed as mean percentages $\pm \mathrm{SD}$. FlowLaar, Flowers of Launaea arborescens.

\section{Invertebrate availability}

A total of 1,499 invertebrates was sampled. Of these, $92.5 \%(1,386)$ were collected on the ground and $7.5 \%$ (113) from the vegetation. The main groups found on the ground were Formicidae $(56.2 \%)$, Araneae (12.6\%), Lepismatidae (12.8\%) and Coleoptera (14.2\%) (Table 2). On vegetation, ants were again the best represented group, comprising $51.3 \%$; other groups were Acrididae (11.5\%), Hemiptera $(18.6 \%)$ and Coleoptera (17.7\%). The numbers of molluscs present in abandoned gavias were significantly higher than found in cultivated and ploughed gavias (Kruskal-Wallis test, $\chi^{2}=159 ; d f=2 ; P<0.001$ ). For both ground and vegetation samples, the total availability of invertebrates in cultivated gavias differed significantly from that in the others (Vegetation: $\chi^{2}=39.05 ; d f=2 ; P<0.001$ and Ground: $\chi^{2}=80.25 ; d f=2 ; P<0.001$ ).

Local variations occurred in invertebrate abundance in each gavia type. Cultivated gavias had a higher availability at Lajares and Triquivijate, with an average 


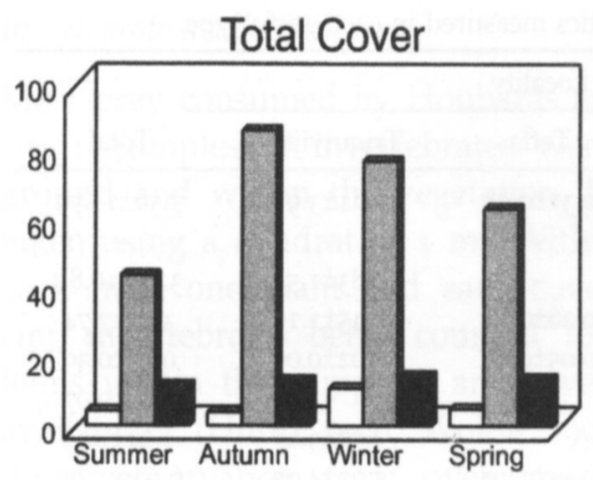

Chenoleoides tomentosa Cover
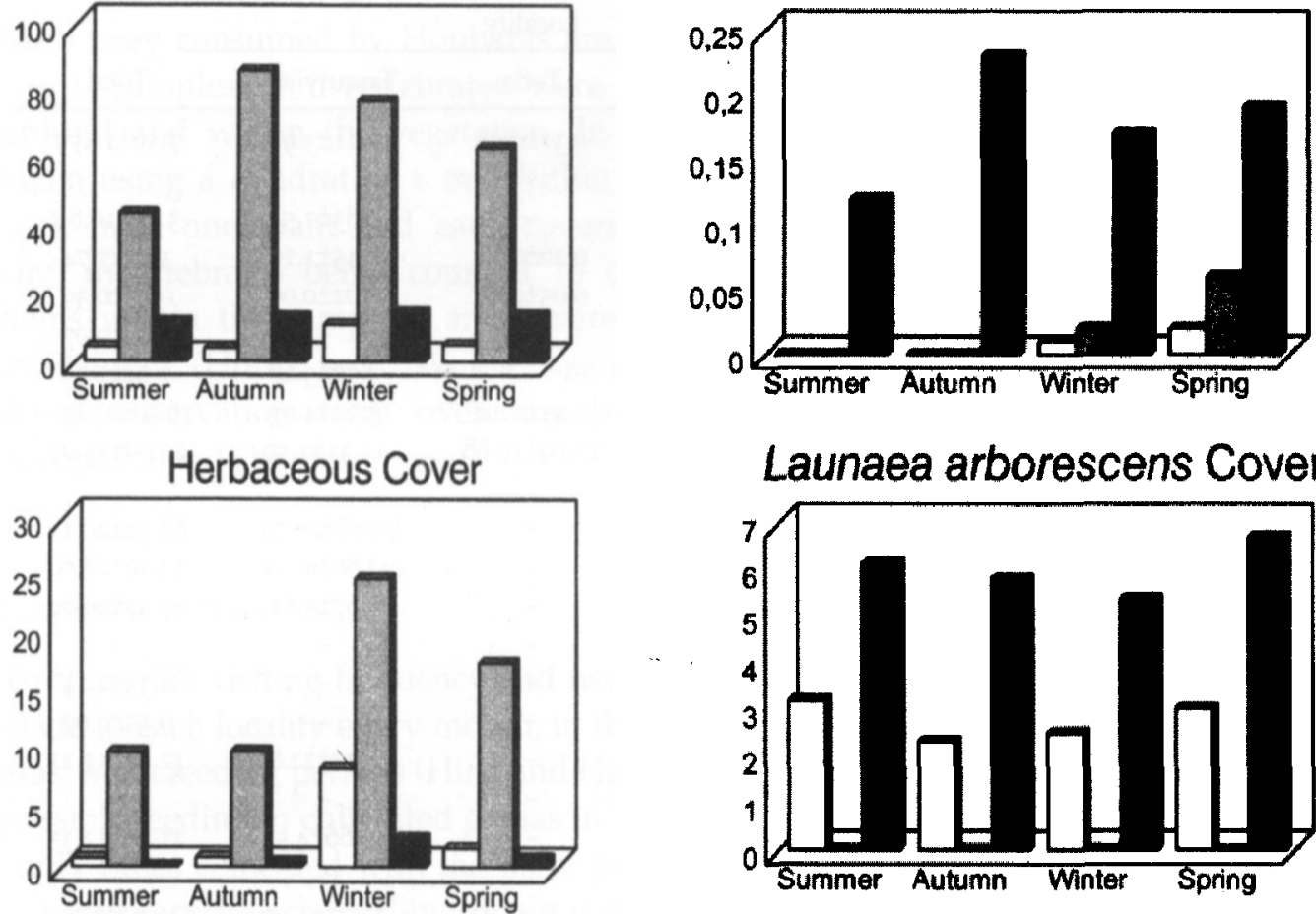

Launaea arborescens Cover
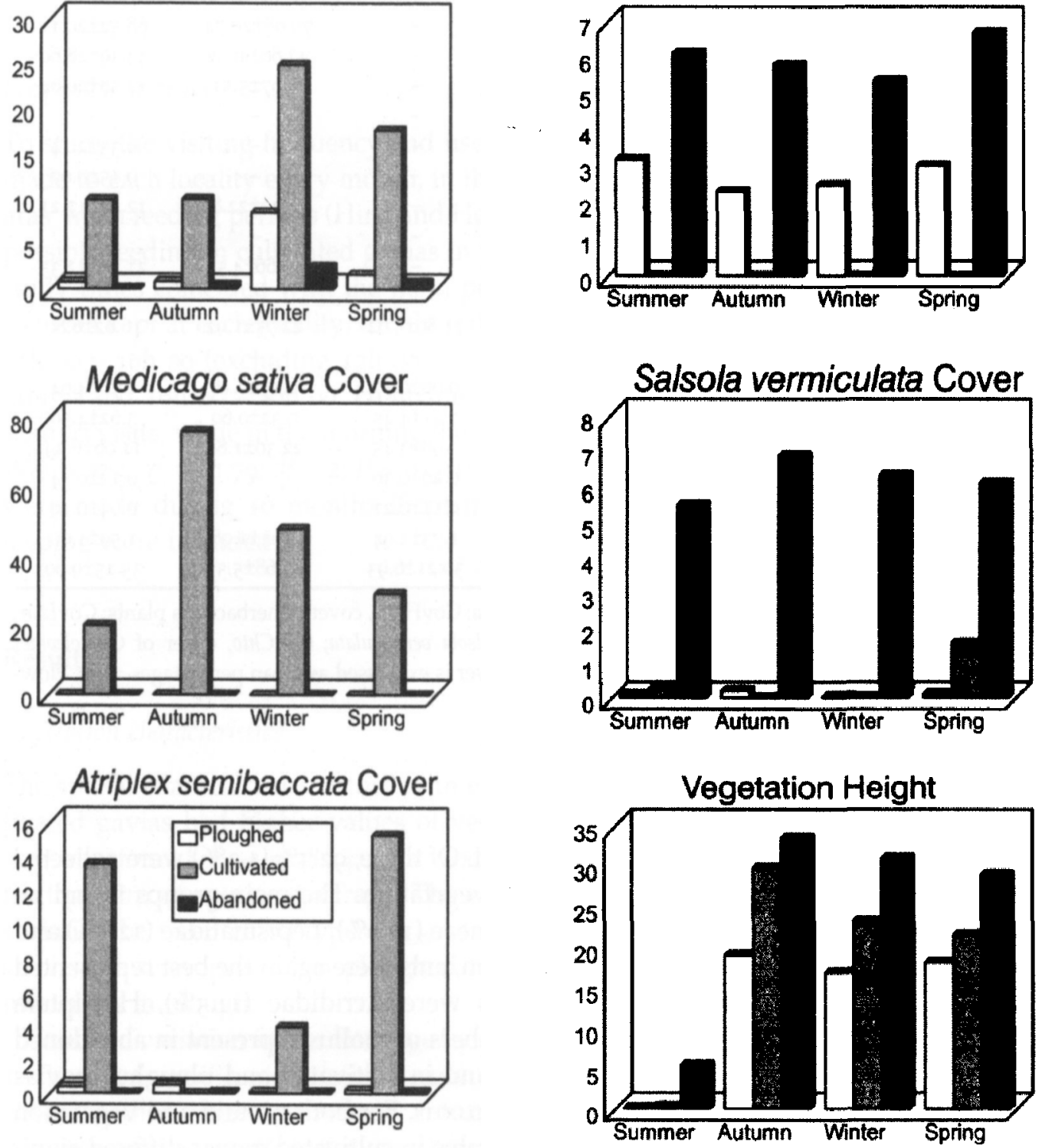

Figure 1. Seasonal variation in vegetation variables measured in each type of gavia on Fuerteventura during the study period (September 1994-August 1995). Cover (\%); height (cm). 
Table 2. Mean number of invertebrates sampled in both environments in each gavia type during the study period in Fuerteventura.

\begin{tabular}{|c|c|c|c|c|c|c|c|c|c|}
\hline \multirow[t]{3}{*}{ Invertebrates } & & \multicolumn{6}{|c|}{ Gavia type } & & \\
\hline & & \multicolumn{2}{|c|}{ Ploughed } & \multicolumn{2}{|c|}{ Cultivated } & \multicolumn{2}{|c|}{ Abandoned } & \multicolumn{2}{|c|}{ Total } \\
\hline & & $\mathrm{Gr}$ & Veg & Gr & Veg & $\mathrm{Gr}$ & Veg & Gr & Veg \\
\hline \multirow[t]{2}{*}{ Formicidae } & Mean & 1.70 & 3.40 & 23.75 & 0.83 & 43.00 & 0.60 & 21.61 & 1.61 \\
\hline & SD & 1.30 & 7.28 & 26.41 & 1.11 & 66.18 & 0.90 & 42.93 & $4 \cdot 36$ \\
\hline \multirow[t]{2}{*}{ Araneae } & Mean & 0.20 & - & 10.17 & - & 4.60 & 0.10 & 4.86 & 0.03 \\
\hline & SD & 0.39 & & 11.11 & & 3.86 & 0.29 & 7.80 & 0.17 \\
\hline \multirow[t]{2}{*}{ Acrididae } & Mean & 0.20 & - & 1.33 & 0.75 & 0.30 & 0.40 & 0.58 & 0.36 \\
\hline & $\mathrm{SD}$ & 0.58 & & 2.50 & 1.06 & 0.87 & 0.65 & $1.6 \mathrm{I}$ & 0.76 \\
\hline \multirow[t]{2}{*}{ Lepismatidae } & Mean & 200 & - & 1.42 & - & 12.50 & - & 4.97 & - \\
\hline & SD & 3.32 & & 1.62 & & 8.47 & & 6.95 & \\
\hline \multirow[t]{2}{*}{ Hemiptera } & Mean & 0.10 & - & 2.08 & 1.50 & 0.50 & 0.30 & 0.86 & 0.58 \\
\hline & SD & 0.29 & & 4.76 & 4.60 & 1.00 & 0.45 & 2.87 & 2.68 \\
\hline \multirow[t]{2}{*}{ Coleoptera } & Mean & 8.20 & 0.20 & 1.00 & 0.67 & $7 \cdot 70$ & 0.90 & $5 \cdot 44$ & 0.56 \\
\hline & SD & 6.69 & 0.39 & 1.76 & 0.78 & 5.53 & 1.53 & 5.92 & 1.03 \\
\hline \multirow[t]{2}{*}{ Zophosis sp. } & Mean & 3.30 & 0.10 & 0.25 & - & 5.30 & 0.30 & 2.81 & 0.11 \\
\hline & SD & $4-31$ & 0.29 & 0.62 & & 3.83 & 0.62 & 3.79 & 0.40 \\
\hline \multirow[t]{2}{*}{ Arthrodeis sp. } & Mean & 3.30 & - & - & - & 0.50 & - & 1.25 & - \\
\hline & SD & 2.93 & & & & 0.67 & & 2.26 & \\
\hline \multirow[t]{2}{*}{ Curculionidae } & Mean & 0.10 & - & - & - & 0.30 & 0.10 & 0.22 & 0.03 \\
\hline & SD & 1.44 & & & & 0.62 & 0.29 & 0.90 & 0.17 \\
\hline \multirow[t]{2}{*}{ Chrysomelidae } & Mean & 0.20 & - & - & - & - & - & 0.06 & - \\
\hline & $\mathrm{SD}$ & 0.58 & & & & & & 0.33 & \\
\hline \multirow[t]{2}{*}{ Coccinellidae } & Mean & 0.40 & - & - & 0.67 & - & 0.50 & 0.03 & 0.36 \\
\hline & SD & 0.29 & & & $0.7^{8}$ & & 0.79 & 0.17 & 0.68 \\
\hline \multirow[t]{2}{*}{ Coleoptera indet. } & Mean & 0.90 & 0.10 & 0.75 & - & 1.70 & 0.10 & 1.08 & 0.06 \\
\hline & SD & 1.00 & 0.29 & 1.71 & & 2.61 & 0.29 & 1.87 & 0.23 \\
\hline \multirow[t]{2}{*}{ Mollusca } & Mean & - & 0.10 & - & 21.58 & - & 283.20 & - & 93.75 \\
\hline & SD & & 0.29 & & 28.00 & & 126.48 & & 139.63 \\
\hline \multirow[t]{2}{*}{ Total Availability } & Mean & 12.30 & $3 \cdot 70$ & $39 \cdot 75$ & 25.42 & 69.20 & 285.50 & 38.61 & 96.92 \\
\hline & SD & 9.83 & 7.57 & 27.28 & 27.86 & $73 \cdot 37$ & 125.99 & 49.06 & 138.89 \\
\hline
\end{tabular}

Gr, Ground, Veg, Vegetation

of 19.2 and 5.9 arthropods respectively, found mainly on the ground. The highest mean values of arthropods in abandoned gavias were at Lajares (11.3). The highest numbers of terrestrial molluscs were observed at Triquivijate (mean: 80.4) $\left(\chi^{2}=29.97 ; d f=2 ; P<0.001\right)$, while the value at Lajares was 37.5 and at Tefía 12.7.

Autumn and spring were the periods with greatest invertebrate availability (Vegetation: Kruskal-Wallis, $\chi^{2}=9.55 ; d f=3 ; P=0.02$, and Ground: logtransformed, Duncan multiple ranks test, $F_{3,128}=3.57 ; P=0.01$ ) (Figure 2), though in cultivated gavias there was no significant difference between seasons (total availability: $\log$-transformed, $F_{3,32}=0.68 ; P=0.56$ ). Ploughed gavias provided more invertebrates in autumn than in winter and summer (Total: Kruskal-Wallis, $\chi^{2}=7.89 ; d f=3 ; P=0.04$, and Ground: Kruskal-Wallis, $\left.\chi^{2}=8.02 ; d f=3 ; P=0.04\right)$; nevertheless, no significant differences were found in the vegetation despite of the apparent tendecy. In abandoned gavias differences were found only between spring and summer, values being higher in spring (log-transfored, Scheffé test, $\left.F_{3,128}=4.15 ; P=0.007\right)$. 


\section{Total}

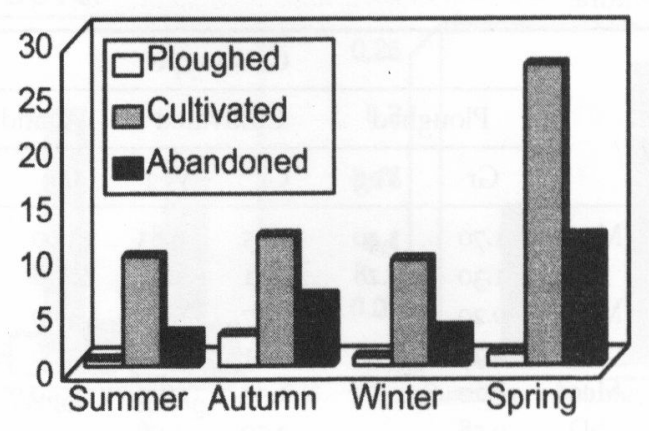

Ground

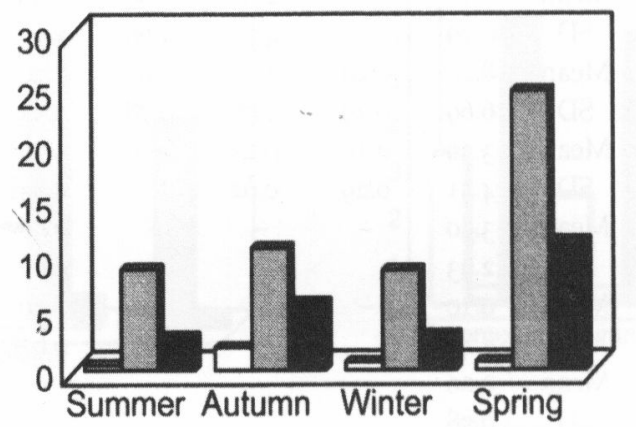

Vegetation

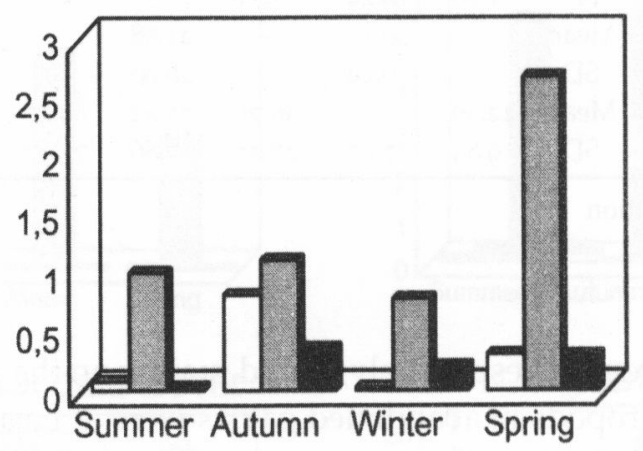

Figure 2. Seasonal variations in invertebrate numbers registered in each type of gavia in both samples.

\section{Frequency of visits}

A total of 521 visits to the gavias by Houbaras was observed during this study; $81(15.5 \%)$ to the abandoned, $139(26.7 \%)$ to the cultivated and $301(57.8 \%)$ to the ploughed ones; the ploughed gavias were visited significantly more often than the other types $\left(\chi^{2}=149.72 ; d f=2 ; P<0.001\right)$.

In general, the pattern of usage by Houbaras of the different gavia types (Table 3) showed correlations with total vegetation cover, herbaceous cover, and alfalfa cover. Correlations with invertebrate abundance were all negative. The use of 
Table 3. Statistically significant values of Spearman rank correlation between the characteristics of different gavia types and the mean number of Houbaras that used that type.

\begin{tabular}{lcccc}
\hline Variable & \multicolumn{3}{c}{ Gavia type } & \\
\cline { 2 - 4 } & Cultivated & Ploughed & Abandoned & Total \\
\hline Covtot & - & $0.62^{* * *}$ & - & $0.27^{* *}$ \\
CovHerb. & - & $0.42^{* *}$ & $0.55^{* * *}$ & $0.25^{*}$ \\
CovMesa & $0.52^{* *}$ & - & - & $0.22^{*}$ \\
CovSave & - & $0.62^{* * *}$ & - & - \\
CovAtse & - & - & - & - \\
CovChto & - & - & - & - \\
CovLaar & - & $0.59^{* * *}$ & - & - \\
No FlLaar & - & - & - & - \\
Height & - & $0.61^{* * *}$ & - & - \\
Invertebrate on ground & - & - & - & $-0.22^{* *}$ \\
Invertebrate over vegetation & - & - & - & $-0.25^{* *}$ \\
Mollusca & - & - & - & $-0.22^{*}$ \\
Total invertebrate & - & - & - & $-0.30^{* *}$ \\
\hline
\end{tabular}

Covtot: total cover; CovHerb, herbaceous cover; CovLaar, Launaea arborescens cover; CovSave, Salsola vermiculata cover; CovAtse: Atriplex semibaccata cover; CovChto: Chenoleoides tomentosa cover; CovMesa, Medicago sativa cover; No FlLaar: number of flowers of Launaea arborescens. ${ }^{*} P<0.05,{ }^{* *} P<0.01$, *** $P<0.001$.

cultivated gavias was correlated with alfalfa cover and that of abandoned gavias with herbaceous cover. The use of ploughed gavias was positively correlated with several variables: total cover, herbaceous cover, Launaea cover, Salsola cover and vegetation height.

Ficus carica was only present in the ploughed gavias and its fruits (figs) are a favoured food item of Houbaras (pers. obs.). Fruits are formed during the summer and are available, when fallen, from June until October. The number of figs available was estimated, for the period August-October 1996, as 310 fruits per tree $(n=21)$. The numbers of Houbaras using these gavias during this period $(n=235)$ were significantly higher than those using them during the rest of the year $\left(n=66 ; \chi^{2}=94.88 ; d f=1 ; P<0.001\right)$.

Of the three localities, Lajares had most visits by Houbaras to gavias (357, or $68.5 \%$ of all visits to the three sites); there were 105 visits recorded at Triquivijate and 59 at Tefia $\left(\chi^{2}=296.39 ; d f=2 ; P<0.001\right)$. Moreover, Houbaras showed a preference for one particular gavia type at each locality. Ploughed gavias were significantly favoured at Lajares $(n=242)$ and Tefía $(n=48)$ (Lajares: $\chi^{2}=192.55$; $d f=2 ; P<0.001 ;$ Tefía: $\left.\chi^{2}=23.20 ; d f=1 ; P<0.001\right)$. At Triquivijate, however, cultivated gavias were used more than others, having $87.6 \%$ of visits $\left(\chi^{2}=140.40\right.$; $d f=2 ; P<0.001)$. This use was related to different variables at each locality. In Lajares the utilization was correlated with Launaea cover $\left(r_{\mathrm{s}}=0.56 ; P<0.001 ; n=\right.$ $36)$, and with the number of Launaea flowers $\left(r_{\mathrm{s}}=0.44 ; P=0.01 ; n=36\right)$. In Tefía, no individual variable explained the use of the gavias. However, in Tefía and Lajares, the presence of figs may have determined the use of gavias. In Triquivijate, the number of Houbaras was correlated with alfalfa cover $\left(r_{\mathrm{s}}=0.59 ; P<\right.$ $0.001 ; n=36)$ and total cover $\left(r_{\mathrm{s}}=0.49 ; P=0.002 ; n=36\right)$.

Gavias were used at all seasons, although during spring a major decline in visits occured. In April no visit by Houbaras was recorded at any locality, while 


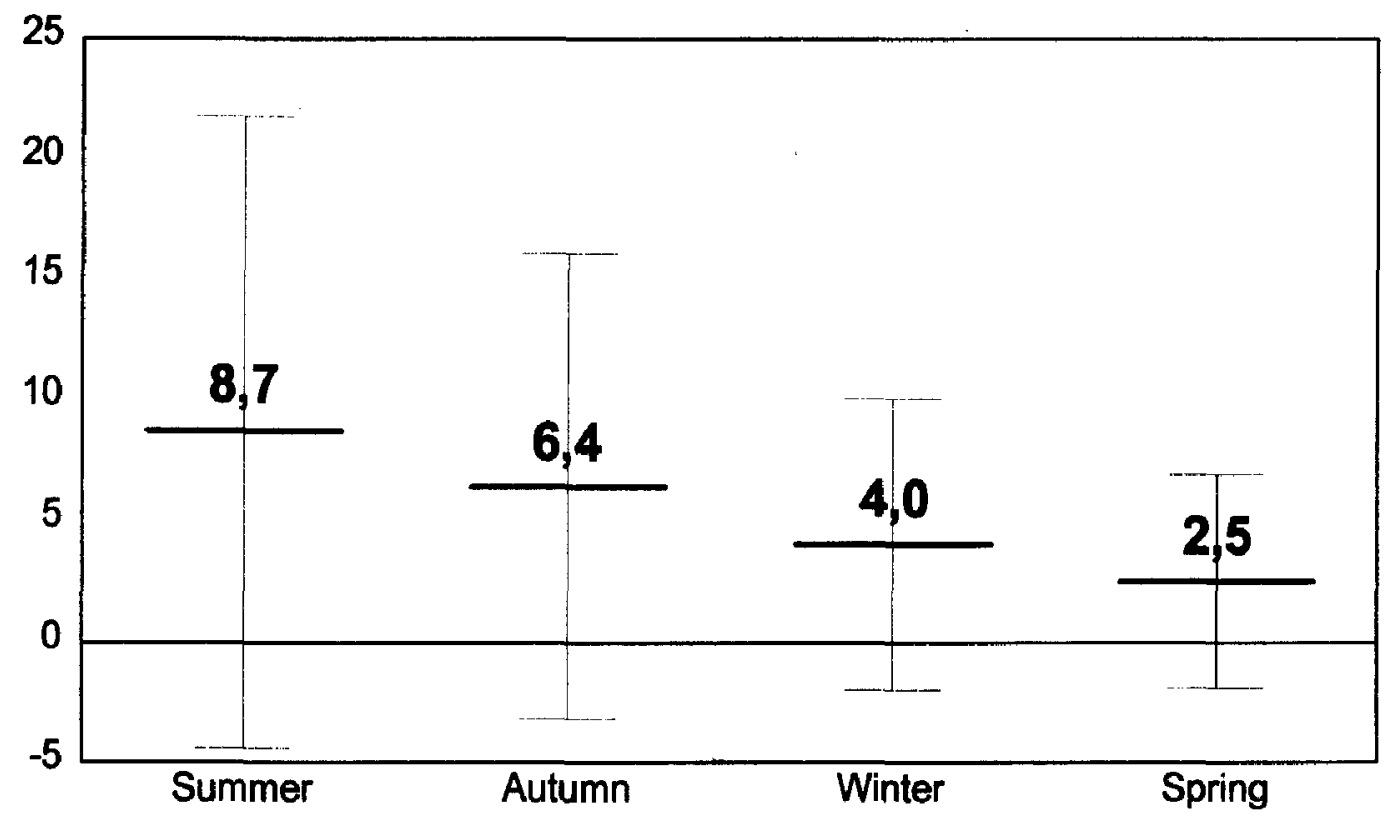

Figure 3 . Seasonal usage of gavias by Houbaras as mean percentages \pm standard deviation of the total number of visits recorded during the year.

summer was the period with most visits $\left(\chi^{2}=100.41 ; d f=3 ; P<0.001\right.$; Figure 3$)$. Also, the selection of different gavia types depended on the season (Figure 4 ): cultivated ones were visited more often during autumn $\left(\chi^{2}=25.46 ; d f=3 ; P<\right.$ 0.001 ), and declined thereafter; ploughed gavias were used more in summer than

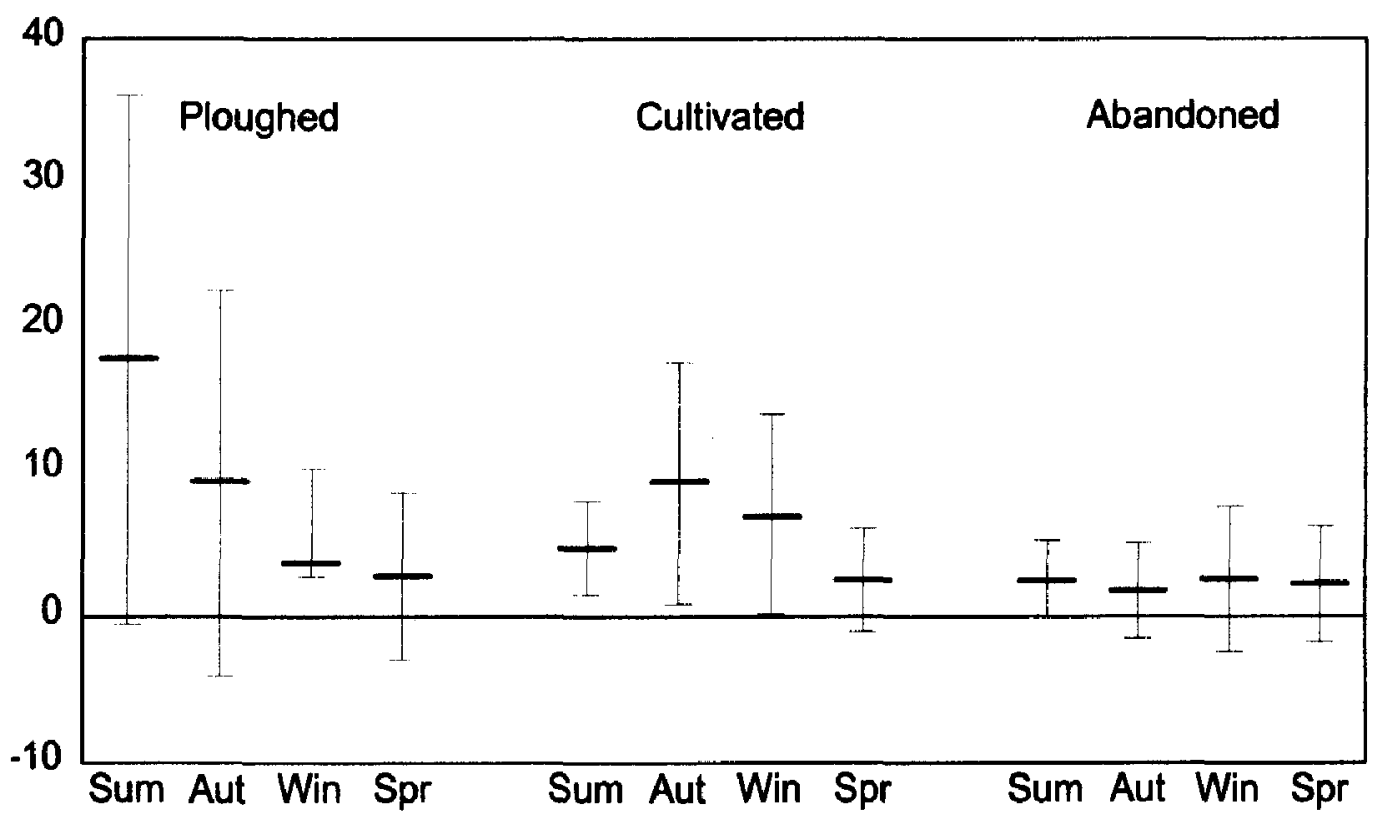

Figure 4. Total number of Houbaras recorded in each gavia type in differents seasons on Fuerteventura (mean \pm standard deviation). Sum, summer; Aut, autumn; Win, winter, Spr, spring. 
in spring $\left(\chi^{2}=143.44 ; d f=3 ; P<<0.001\right)$; no seasonal differences were found in the use of abandoned gavias $\left(\chi^{2}=1.41 ; d f=3 ; P=0.7\right)$.

Houbaras selected gavias on the basis of different variables in different seasons. Thus in winter they selected herbaceous cover $\left(r_{s}=0.46 ; P=0.013 ; n=24\right)$, and in summer total and herbaceous cover $\left(r_{\mathrm{s}}=0.48 ; P=0.018 ; n=24\right.$ and $r_{\mathrm{s}}=$ $0.42 ; P=0.039 ; n=24$, respectively). Also during summer the figs fruited, which was important in influencing the use of ploughed gavias. During spring the birds showed a negative correlation with invertebrate abundance (Vegetation: $r_{\mathrm{s}}=-$ $0.54 ; P=0.039 ; n=24$ and Ground: $r_{\mathrm{s}}=-0.50 ; P=0.013 ; n=24$ ). In autumn, no relationship was found between use of gavias and the variables studied.

Houbaras appeared to have difficulty in entering fenced fields. The number visiting fenced gavias during the study was lower (17) than those visiting gavias without fences (79) $\left(\chi^{2}=40.04 ; d f=1 ; P<0.001\right)$.

\section{Discussion}

In all three localities the structural and floristic components of the vegetation in gavias were very important in habitat selection by Houbaras on Fuerteventura (Bannerman 1963, Collins 1984, Martín et al. 1996), as they are also for the Great Bustard in the Iberian peninsula (Alonso and Alonso 1990, Hidalgo de Trucios and Carranza 1990, Hellmich 1991). In other studies of habitat selection by birds the availability of animal prey has been found to be fundamental (Johnson 1980, Karr and Brawn 1990) but in the present study this does not seem to be decisive, as has also been found for the subspecies $C$. $u$. macqueenii (Seddon and van Heezik 1996).

Houbaras selected cultivated gavias on the basis of alfalfa cover, a plant with high protein and fibre content (Jarrige 1981 in Martínez 1991b). Furthermore, alfalfa is a predictable resource, being available all year. When cultivated gavias were abandoned during the study, Houbaras stopped visiting them, while in cultivated gavias only $300 \mathrm{~m}$ away, up to 13 birds were counted in the same period of time. The presence of alfalfa in cultivated gavias thus seems to be their main attraction. Abandoned gavias wrere used as initial feeding areas before moving to other gavia types and the birds consumed any items they found there. Such abandoned areas were favourable to plants because of the water-retaining banks which enclosed them (Collins 1984). Furthermore, these gavias had high vegetation, an important factor in habitat selection for greater shrub height may be related to the Houbaras' need for concealment (Martín et al. 1996).

In ploughed gavias, several variables appeared to be important to Houbaras, while ploughed fields are also used by C. u. maqueenii (Lavee 1985). Figs are the principal reason for the occurrence of Houbaras in ploughed gavias. This relationship between Houbaras and figs was observed for two consecutive years so the birds may have selected this habitat by remembering the presence of this resource (Hildén 1965, Wiens 1985). The use of these fruits was observed again in the summers of 1996 and 1997 (J. Hellmich and C. Ramírez verbally). Figs fruit twice a year with only a short time in summer when no figs are present (Blanco 1996). In Tefía, visits by Houbaras to ploughed gavias (with fig trees) occurred only during the two fruiting periods.

The study localities differed in the number, distribution and characteristics of 
each gavia type. That the birds sometimes gathered in those habitats with the highest quality food resources (Alonso et al. 1987) may explain the different frequency of visits to each locality. On the other hand, the level of the Houbara population might determine the number of birds seen in each locality. Martin et al. (1997) found in the area of Lajares (Reserva de Lajares-Tindaya-EsquinzoTaca-Cotillo) a total of 43 birds, with a density of 1.14 birds per $\mathrm{km}^{2}$; in Tefía (Llano de La Laguna and La Rosa de Ucala) eight birds were observed (density: 0.48 birds $/ \mathrm{km}^{2}$ ), and at Triquivijate (La Vega Vieja-Cañada de Lorenzo-Los Llanos de las Salinas-Los Alares-Las Pocetas) the population was 59 birds (2.62 birds $\left(\mathrm{km}^{2}\right)$. Lajares had the highest number of visits by Houbaras recorded in the present study but with fewer birds than Triquivijate, so the differences between localities may depend more on resource richness than on the size of the local Houbara population, as also suggested for the species in Saudi Arabia (Seddon and van Heezik 1996).

The low number of Houbaras using gavias in spring may be due to the birds' return to their breeding areas, as also noted in Saudi Arabia (Seddon and van Heezik 1996). From December the males spend less time looking for food and more time in courtship, while females are looking for nesting sites. As breeding areas are very different from feeding areas, it is inevitable that Houbaras reduce their visits to gavias at this time.

Seasonal variation in habitat selection by birds is affected by variation in rainfall, which influences the development of vegetation (particularly annuals) and invertebrate activity (Wiens et al. 1986, 1993). The availability of food resources (perhaps affected by precipitation) outside of gavias may also be important (Collins 1993, Seddon and van Heezik 1996): if Houbaras found enough food outside gavias, visits to them may be reduced. According to Collins (1993), Houbaras concentrate feeding activity on whatever resources are available, so food and feeding preferences vary greatly in different areas and at different times of the year (Mian 1986).

Gavias provide a food resource for Houbaras which is predictable and of easy access, providing a real advantage in those periods when there is reduced food availability in other habitats. They therefore contribute to the conservation of the Houbara population on Fuerteventura.

\section{Acknowledgements}

I am very grateful to Manuel Nogales for his invaluable assistance during the development of this study, for making useful suggestions and for his comments on the paper. Aurelio Martín, Juan L. Rodríguez Luengo and José María Fernández Palacios revised and improved early drafts of the manuscript. Vicente Quilis took part in the early stages of this study and, with Alfredo Valido, Juan A. Lorenzo, Juan D. Delgado and Miguel A. Hernández, made valuable suggestions. José J. Naranjo and Guillermo Delgado also deserve thanks for helping me during the fieldwork. Duncan Brooks offered critical suggestions and checked the English. Comments from Mario Diaz and an anonymous referee were also very helpful. I thank Carlos Ramírez for his hospitality and help during my stay on Fuerteventura, and Joachim Hellmich for giving me some data on cultivated field use in 1996 and 1997. I also thank the Instituto Nacional de Meteorología (Canarias Orientales). This work was supported by the Viceconsejería de Medio Ambiente of the Canary Islands government. 


\section{References}

Alonso, J. C. and Alonso, J. A. (1990) Parámetros demográficos, selección de hábitats y distribución de la avutarda (Otis tarda) en tres regiones españolas. Madrid: Colección Técnica, ICONA.

Alonso, J. C., Alonso, J. A. and Veiga, J. P. (1987) Flocking in wintering Common Cranes Grus grus: influence of population size, food abundance and habitat patchiness. Ornis Scand. 18: 53-60.

Alonso, J. A., Alonso, J. C., Martín, E. and Morales, M. B. (1995) La Avutarda en la Reserva de Las Lagunas de Villafáfila. Instituto de Estudios Zamoranos (CSIC). Zamora: Diputación de Zamora.

Bannerman, D. A. (1963) Birds of the atlantic islands, I. A history of the birds of the Canary Islands and of the Salvages. Edinburgh: Oliver and Boyd.

Blanco, E. (1996) Higos y brevas: la curiosa fructificación de la higuera. Quercus 120: 8-11.

Brown, J. S., Kotler, B. P. and Mitchell, W. A. (1994) Foraging theory, patch use, and the structure of a Negev Desert granivore community. Ecology 75: 2286-2300.

Collins, D. R. (1984) A study of the Canarian Houbara Bustard Chlamydotis undulata fuertaventurae, with special reference to its behaviour and ecology. Unpubl. thesis, University of London.

Collins, D. R. (1993) The diet of the Houbara Bustard Chlamydotis undulata fuertaventurae in the Canary Islands. Bol. Mus. Mun. Funchal 2: 57-67.

Cooper, R. J. and R. C. Whitmore (1990) Arthropod sampling methods in ornithology. Stud. Avian Biol. 13: 29-37.

Cramp, S. and Simmons, K. E. L. (1980) Handbook of the birds of Europe, the Middle East and North Africa, II. Oxford: Oxford University Press.

Domínguez-Casanova, F. (1989) The Houbara Bustard in the Canary Islands (Spain): towards a recovery plan. Bustard Stud. 4: 42-51.

Domínguez-Casanova, F. and Díaz, G. (1985) Plan de recuperación de la Hubara Canaria. ICONA. Unpubl. report.

Galván, M. and Criado, C. (1985) Fuerteventura. Pp. 243-296 in L. Afonso, ed. Geografia de Canarias. Santa Cruz de Tenerife: Editorial Interinsular Canaria.

Hellmich, J. (1991) La Avutarda en Extremadura. Monografía de Alytes 2. Mérida: ADENEX.

Hidalgo de Trucios, S. J. and Carranza, J. (1990) Ecología y Comportamiento de la Avutarda (Otis tarda L.). Cáceres: Servicio de Publicaciones de la Universidad de Extremadura.

Hildén, O. (1965) Habitat selection in birds. Ann Zool. Fenn. 2: 53-75.

Hinz, C. and Heiss, E. M. (1989) The activity patterns of Houbara Bustards: aspects of a field study in the Canary Islands. Bustard Stud. 4: 68-79.

Hutto, R. L. (1990) Measuring the availability of food resources. Stud. Avian Biol. 13: 20-28.

Johnsgard, E. A. (1991) Bustards, hemipodes, and sandgrouse. Oxford: Oxford University Press.

Johnson, D. H. (1980) The comparision of usage and availability measurements for evaluating resource preference. Ecology 61: 65-71.

Karr, J. R. and Brawn, J. D. (1990) Food resources of understorey birds in Centra Panamá: quantification and effects on avian populations. Stud. Avian Biol. 13: 58-64.

Kent, M. and Coker, P. (1992) Vegetation description and analysis: a practical approach. London: Belhaven Press.

Krebs, J. R. and Davies, N. B. (1993) An introduction to behavioural ecology, Third edition. Oxford: Blackwell Scientific Publications.

Lavee, D. (1985) The influence of grazing and intensive cultivation on the population size of the Houbara Bustard in the Northern Negev in Israel. Bustard Stud. 3: 103-107.

Martín, A., Nogales, M., Hernández, M. A., Lorenzo, J. A., Medina, F. M. and Rando, J. C. (1996) Status, conservation and habitat selection of the Houbara Bustard Chlamydotis 
undulata fuertaventurae on Lanzarote (Canary Islands). Bird Conserv. Internatn. 6: 229239.

Martín, A., Lorenzo, J. A., Hernández, M. A., Nogales, M., Medina, F. M., Delgado, J. D., Naranjo, J. J., Quilis, V. and Delgado, G. (1997) Distribution, status and conservation of the Houbara Bustard Chlamydotis undulata fuertaventurae Rothschild and Hartert, 1894, in the Canary Islands, November-December 1994. Ardeola 44: 61-69.

Martínez, C. (1991a) Patterns of distribution and habitat selection of a Great Bustard (Otis tarda) population in northwestern Spain. Ardeola 38: 137-147.

Martínez, C. (1991b) Selección de microhábitat en una población de Avutarda (Otis tarda) en un medio agrícola. Doñana Acta Vertebrata 18: 173-185.

Martínez, C. and de Juana, E. (1995) El Sisón. La Garcilla 92: 16-19.

Marzol-Jaén, M. V. (1984) El clima de Canarias. Pp. 157-202 in L. Alfonso, ed. Geografía de Canarias. Santa Cruz de Tenerife: Editorial Interinsular Canaria.

Mian, A. (1986) A contribution to the biology of Houbara: some studies on gizzard contents from 1983-84 wintering population in the Western Baluchistan. Pakistan J. Zool. 18: $363-370$.

Osborne, P. (1984) Bird numbers and habitat characteristics in farmland hedgerows. J. Appl. Ecol. 21: 63-82.

Pyke, G. H. (1984) Optimal foraging theory: a critical review. Ann. Rev. Ecol. Syst. 15: 523575 .

Pyke, G. H., Pulliam, H. R. and Charnov, E. L. (1977) Optimal foraging: a selective review of theory and tests. Q. Rev. Biol. 52: 137-154.

Rice, J. B., Anderson, B. W. and Ohmart, R. D. (1984) Comparison of the importance of different habitat attributes to avian community organization. J. Wildl. Management. 48: $895-911$.

Rotenberry, J. T. and Wiens, J. A. (1980) Habitat structure, patchyness, and avian communities in North American steppe vegetation: a multivariate analysis. Ecology 61: 12281250 .

Schoener, T. W. (1971) Theory of feeding strategies. Ann. Rev. Ecol. Syst. 2: 369-404.

Seddon, P. J. and Van Heezik, Y. (1996) Seasonal changes in Houbara Bustard Chlamydotis undulata macqueenii numbers in Harrat $\mathrm{Al}$ Harrah, Saudi Arabia: implications for managing a remnant population. Biol. Conserv. 75: 139-146..

Thompson, F. R. and Fritzell, E. K. (1989) Habitat use, home range, and survival of territorial male Ruffed Grouse. J. Wildl. Management. 53: 15-21.

Tucker, G. M. and Health, M. F. (1994) Birds in Europe: their conservation status. Cambridge, U.K. BirdLife International (BirdLife Conservation Series 3).

Wiens, J. A. (1985) Habitat selection in variable environments: shrubsteppe birds. Pp. 227251 in M. L. Cody, ed. Habitat selection in birds. Orlando: Academic Press.

Wiens, J. A., Rotenberry, J. T. and Van Horne, B. (1986) A lesson in the limitations of field experiments: shrubsteppe birds and habitat alteration. Ecology 67: 365-376.

Wiens, J. A., Stenseth, N. C., Van Horne, B. and Ims, R. A. (1993) Ecological mechanisms and landscape ecology. Oikos 66: 369-380.

Wolda, H. (1990) Food availability for an insectivore and how to measure it. Stud. Avian Biol. 13: 38-43.

FÉLIX M. MEDINA

Department of Zoology, University of La Laguna, E-38271 La Laguna, Tenerife, Canary Islands, Spain. 